\section{Assessment of the protective function of forests against debris flows in a gorge of the Slovenian Alps}

\author{
Gal Fidej ${ }^{(1)}$, Matjaž Mikoš ${ }^{(2)}$, Tihomir Rugani ${ }^{(1)}$, Jernej Jež ${ }^{(3)}$, Špela \\ Kumelj $^{(3)}$, Jurij Diaci ${ }^{(1)}$
}

Protection forests play an important role in mitigating the influence of natural hazards. Despite the growing need for protective functions due to aging forests and increased risk of natural disturbances, active forest management has become increasingly uncommon across the Alps. Active management of protection forests can be facilitated by state subsidies. This requires an objective delineation of forests with a direct protection function and the development of silvicultural techniques that mitigate natural hazards. A study of protection efficiency of beech-dominated forests was performed in the Soteska gorge in NW Slovenia, where a main state road and railway are at risk from debris flows and rockfall. We assessed the starting points of debris-flow hazard based on a small-scale geological survey of the terrain characteristics and a local debris flow susceptibility map. We applied the TopRunDF model for determination of the run-out zones. Forest structure data were obtained from 26 sample plots. A detailed description and delineation of forest stands was performed. The results showed that these forests play an important role in the protection of infrastructure. Forest protection efficiency can be improved by stand thinning for stability and careful planning of regeneration patches over time and space. In areas where silvicultural measures cannot provide sufficient protection, technical measures are needed. Since these forests have not been managed for several decades, natural disturbances (windthrow) are frequent. Research findings suggest that regular assessment and management of these beech-dominated protection forests are necessary, contrary to the current practice of non-management in protection forests in Slovenia.

Keywords: Protection Forest, Protection Function, Debris Flow, TopRunDF, Beech Forest

\section{Introduction}

Traditional land use (agriculture and forestry) is being abandoned in the Alps due to socioeconomic changes, while an increasingly larger area is being used for tourism and infrastructure, which requires protection from natural hazards. Forests provide permanent protective functions, but only if they are properly and sustainably managed (Ott et al 1997, O'Hara 2006, Mizunaga et al. 2010). There has been a general decline in forest management in Europe (Forest Europe 2010) and in the Alps in particular, where it is difficult to achieve positive economic returns (Schütz 1996). Climate change has increased the frequency of extraordinary weather phenomena, which causes higher risk from natural hazards and weakening of forest stability (Seidl et al. 2011). In many Alpine countries, state subsidies are used to facilitate the management of forests with direct protective functions (Mayer \& Ott 1991, Brang et al. 2006). In order to maximize protective effects with minimal costs, a thorough under-
(1) Biotechnical Faculty, University of Ljubljana, Ljubljana (Slovenia); (2) Faculty of Civil and Geodetic Engineering, University of Ljubljana, Ljubljana (Slovenia); (3) Geological Survey of Slovenia, Ljubljana (Slovenia)

@ Gal Fidej (gal.fidej@bf.uni-lj.si)

Received: Mar 21, 2013 - Accepted: Feb 24, 2014

Citation: Fidej G, Mikoš M, Rugani T, Jež J, Kumelj Š, Diaci J, 2015. Assessment of the protective function of forests against debris flows in a gorge of the Slovenian Alps. iForest 8: 73-81 [online 2014-06-17] URL: http://www.sisef.it/iforest/contents/?id=ifor0994-007

Communicated by: Raffaele Lafortezza standing of natural hazards, their impact areas, and the potential role of forests is necessary (Lopez Saez et al. 2011). A detailed delineation of forest areas with direct protective functions is necessary to determine the areas where state subsidies should be directed. In addition, forest profile models must be developed to inform silvicultural measures and to verify their success (Mayer \& Ott 1991, Berger \& Rey 2004, Frehner et al. 2005).

In Switzerland a method for the delineation of forests with direct protection functions was developed as part of the Silvaprotect$\mathrm{CH}$ project: a standardized delineation of protection forests at the state level. The procedure involves multiple, stepwise modules that generate the actual forest areas with direct protection functions (Giamboni \& Wehrli 2008). In France, the zoning classification of mountain forests with direct protection functions and the mapping of hazards and prohibition of the construction of infrastructure in risk areas were identified as the most effective preventive approach to ensure the maintenance of protective functions (Berger $\&$ Rey 2004). In Austria, a distinction is made between two types of protection forests: site-protection forests and infrastructure-protection forests, the latter also including forests that protect against noise and light pollution (Schima \& Singer 2008). Delineation methods of forests in which slope processes (e.g., erosion, landslides, debris flow, etc.) are present differs among the federal states (Ziegner 2002).

The negative effects of disturbances are best mitigated by uneven aged forests, where the presence and distribution of trees provide protection against natural hazards, and the ability to replace damaged trees with existing regeneration provides elasticity (O'Hara 2006). For such forests it is necessary to determine a (modified) selection forest target profile. In Switzerland the NaiS - Nachhaltigkeit und Erfolgskontrolle im Schutzwald is used for the management of protection forests (Frehner et al. 2005). The method is used to assess a protection forest by comparing the current state of a stand with the target profile for each site and natural hazard (Brang et al. 2006). Motta \& Haudemand (2000) evaluated protection forests in a similar way in Italy.

Despite extensive research and development projects on Alpine forests and protective functions (Ott et al. 1997, Brang et al. 2006), there are relatively few studies of beech protection forests, even though beech forests are the potential natural vegetation of nearly the entire boundary of the Alpine range. There are even fewer studies of beech protection forests in southeastern Europe, where beech is the dominant tree species. Beech is a species with several specific cha- 
racteristics: seeds are produced unevenly and only occasionally in abundance (Korpel 1995); the plasticity of beech canopies (lateral growth) quickly closes canopy gaps, restraining the growth of regeneration (Ellenberg 1996); regeneration is in gaps and under closed canopy. Beech forests have a natural tendency towards vertically even structured composition (Leibundgut 1982, Otto 1994). Beech is a shade tolerant species, but does not tolerate long-term, almost complete canopy closure, particularly under its own closed canopy (Meyer et al. 2003). Additionally, the asymmetry of beech crowns, especially noticeable on slopes, makes it difficult to execute felling in the desired direction and to protect advance regeneration. Maintaining a sustainable selection structure is, therefore, more difficult in beech forests. In general, the selection management of pure beech requires slightly lower growing stock and more frequent interventions than mixed beech selection systems (Schütz 2001a). Forest vegetation has a major effect on the stability of slopes by influencing hydrological processes (which affect water content in the soil and the pore pressure) and soil mechanical structure (which affects soil strength). The latter is performed by two root actions. Firstly, small flexible roots mobilize their tensile strength by root-soil friction and thereby increase the compound matrix (soil-fibre) strength. Secondly, large roots intersect the shear surface and act as individual anchors that eventually slip through the soil without braking, thereby mobilizing a soil-root friction force instead of the entire tensile strength (Bischetti et al. 2005, 2009).

As a type of mass movement of sediments on slopes or torrent channels, debris flows have reconfigured the terrain of Slovenia and their frequency has been increasing. Dispersed settlement and the dense network of transport routes require a detailed study of hazards that debris flows pose to the environment (Sodnik \& Mikoš 2006, Lopez Saez et al. 2011). Furthermore, Slovenia does not yet have a much-needed legal basis for preventive protection from increasingly frequent debris flows (Cetina et al. 2006, Mikoš et al. 2004, Mikoš et al. 2006). Collaboration among disciplines such as forestry, hydrology, and geology is required for the implementation of legislation and the determination of impact areas of phenomena such as erosion, debris flows, and landslides.

NW Slovenia has frequent intensive downpours and high precipitation compared to the rest of the Alps (Frei 1995). Days with 100 $\mathrm{mm}$ of precipitation are not infrequent and the highest daily precipitation in Slovenia has been recorded in nearby Bohinj where over $400 \mathrm{~mm}$ of rain fell in 24 hours (KajfežBogataj 1996). High precipitation is a condition for the occurrence of debris flows on geomorphologically heterogeneous, erodible topography, such as the Soteska study area. In the broader region, beech forms natural stands that range from the lowlands up to the upper timberline (1800-2000 m a.s.1.). Stands in Soteska have been ageing due to lack of management. In the transition from the optimal phase to the regeneration phase, a stand breaks down, resulting in reduction of its protection function (Motta \& Haudemand 2000). The degree of stand breakdown is also determined by disturbances in forest ecosystems (Picket \& White 1985). Rockfalls, avalanches as well as windthrow events drive stand development. If their magnitudes are sufficiently small, they exert a positive impact on the regeneration dynamics of forest stands (Dorren \& Berger 2006), but at greater magnitudes or in more sensitive forests, they can completely interrupt the protective functions of a forest for decades (Mayer \& Ott 1991). Given the geomorphological characteristics of the site, the history of non-management, and the infrastructure present downslope, the forests in Soteska are an ideal case study for the methodology of delineation of forests with direct protection function, and for the development of planning tools for the management of protection forests.

Our objectives were to: (i) carry out spatially-explicit modeling to identify areas where debris flows may occur; (ii) assess the protective effect of forest stands against debris flows; (iii) compare the actual state of the structural characteristics of the forest with a target profile; and (iv) analyse the feasibility and suitability of silvicultural measures.

\section{Materials and methods}

\section{Study area}

The Soteska gorge is a narrow alpine valley along the Sava Bohinjka River (NW Slovenia) that drains the Bohinj Lake, and, together with the Sava Dolinka River, forms the Sava River (the largest and longest river in Slovenia). The study area consists of 207 ha of protection forests in which regular cutting is restricted according to the 1993 Forest Act (Official Gazette 1993). Altitudes range from about 470 m a.s.l. (Sava Bohinjka River) up to $1200 \mathrm{~m}$ a.s.l. The slopes are very steep (mean slope angle of $35^{\circ}$ ) and include numerous cliff faces. The coarse-scale topography is very heterogeneous and is characterized by highly dissected slopes and abundant rock outcrops and cliffs. The slopes on the right bank of the river are dominated by northern, northwestern, and western expositions. Stoniness and rockiness are present on almost all plots, indicating relatively shallow soils. Old screes are mostly overgrown with forest, though there are individual exposed scree sections with little soil. The dominant soil type is moderately deep to shallow, strongly skeletal moder rendzinas, which have a dense interconnected root system and are heavily water-logged, humus-rich, not very acidic, and intermediately to well-supplied with nutrients (FMP 2003). Soteska is characterized by a cool and humid climate, with abundant precipitation. The number of days with precipitation of at least $1 \mathrm{~mm}$ in this part of Slovenia is over 140 (ARSO 2006). Average annual precipitation at the nearest meteorological station (Stara Fužina, $547 \mathrm{~m}$ a.s.l., 1971-2000) is $2250 \mathrm{~mm}$. Average temperature is $-2.0{ }^{\circ} \mathrm{C}$ in the coldest month (January) and $17.6{ }^{\circ} \mathrm{C}$ in the warmest (July). Average annual temperature is $7.9^{\circ} \mathrm{C}$.

Debris flows are created by a sufficient quantity of torrential water, which collects due to the damming of surface water or, more frequently, due to strong local precipitation (Wieczorek \& Glade 2005). The dominant association in this environment is Anemone trifoliae-Fagetum, which grows at 600-1200 m a.s.1. on predominantly steep slopes on all exposures. It is a zonal association of the Alpine phytogeographical area of the Illyrian floral province. European beech (Fagus sylvatica L.) forests have a stable biocenotic structure (Marinček \& Carni 2002). European beech populates the slopes of Soteska from the bottom to the edge of the plateau, occasionally transitioning to mixed silver fir (Abies alba Mill.) beech forest sites, which dominate the mountain plateau above Soteska. On steep slopes and on convex sites, Alpine beech forests transition to beech and European hop-hornbeam (Ostrya carpinifolia Scop.) or even to European hop-hornbeam and manna ash (Fraxinus ornus L.) forests. Data on past management indicates very low cutting intensities that did not exceed $1 \mathrm{~m}^{3} \mathrm{ha}^{-1}$ year ${ }^{-1}$. Most of the recorded cutting involved sanitary cuts following windbreak (FMP 2003). Forest chronicles and past forest management plans for the area indicate frequent windthrow events (1984, 1989, 1994, 1995, 1996, 1997, 2005 , and 2009).

\section{Data collection}

In 2010/2011 we established 26 circular permanent sample plots of $500 \mathrm{~m}^{2}$ in size (12.62 m radius) on intersections of a $200 \mathrm{x}$ $200 \mathrm{~m}$ grid on the slopes of the right bank of Sava Bohinjka River. If a plot was obstructed by overhead power lines or if it was on inaccessible rocks or ditches, it was moved by 50 or 100 meters to ensure sufficient coverage of the studied forest. As part of the plot inventory we measured all living trees with diameter at breast height $(\mathrm{DBH}) \geq 10$ $\mathrm{cm}$. We recorded tree species, azimuth, distance to plot center, and DBH. We used a SUUNTO compass, diameter tape, and Haglöf Vertex (model: Laser VL402).

We performed a detailed description of the forest stands, including species composition, 
diameter structure by $20 \mathrm{~cm}$ DBH classes (A: $10-30 \mathrm{~cm}$; B: $30-50 \mathrm{~cm}$; $:>50 \mathrm{~cm}$ ), crown symmetry, and slope gradient. Regeneration on the plots was counted by species and classified into two size classes: seedlings $(10 \mathrm{~cm} \leq \mathrm{H}<1.3 \mathrm{~m})$, and saplings $(1.3 \mathrm{~m} \leq$ $\mathrm{H}$, and $\mathrm{DBH}<10 \mathrm{~cm})$. We calculated the proportion of tree species by diameter class and growing stock. Due to significant differences among the sample plots, we divided the data into two strata: sample plots on debris flow impact areas and other (hereafter "other") sample plots. We compared the actual forest structure and the target selection structure by analyzing the frequency distribution of trees in $5 \mathrm{~cm}$ diameter classes (i.e., $1^{\text {st }}$ diameter class $=0-4 \mathrm{~cm} ; 2^{\text {nd }}$ diameter class: $5-9 \mathrm{~cm}$; etc.), frequency of regeneration by tree species, growing stock, and by assessment of forest texture. The shapes of frequency curves were analyzed according to Janowiak et al. (2008).

The Geological Survey of Slovenia (GSS) created a geological map of the study area at a 1:5000 scale based on a field survey. A detailed geological map of the study area was created as an input for the debris flow susceptibility map of the Soteska gorge (Fig. 1). General lithological and structural geological data were taken into account in the creation of the geological map, with special emphasis on the identification of unconsolidated sediments such as scree deposits that can be involved in mass movement processes.

The debris flow susceptibility map was created with a methodology that the GSS developed for different spatial resolutions and different types of mass movements (e.g. landslide, mass-flow, rockfall). Such methodology is comprised of four consecutive phases that involve a synthesis of archived data, geostatistical modeling with the GSS algorithm (Komac 2005), elaboration of a geohazard map and field verification of the most susceptible areas. The mapping process was first tested in the municipality of Bovec, at a 1:25000 scale (Bavec et al. 2005). In addition to data on lithology, crushed tectonic zones, and distance from structural elements, the impact analysis and creation of the susceptibility model included elevation data, slope and curvature, distance to surface waters, energy potential of streams, and 48hour rainfall intensity. As a finished product, the model is transferable and compatible with all levels of warning and decision-making; it can be directly applied in the creation of spatial plans and is therefore an effective tool for the protection from geological hazards.

We modeled debris flows with the Top Run Debris Flow (TopRunDF) model, version 1.1. The model is a tool for the two-dimensional run-out simulation of the debris flow deposit phase on debris cones. TopRun DF produces two estimates: (1) an inundated

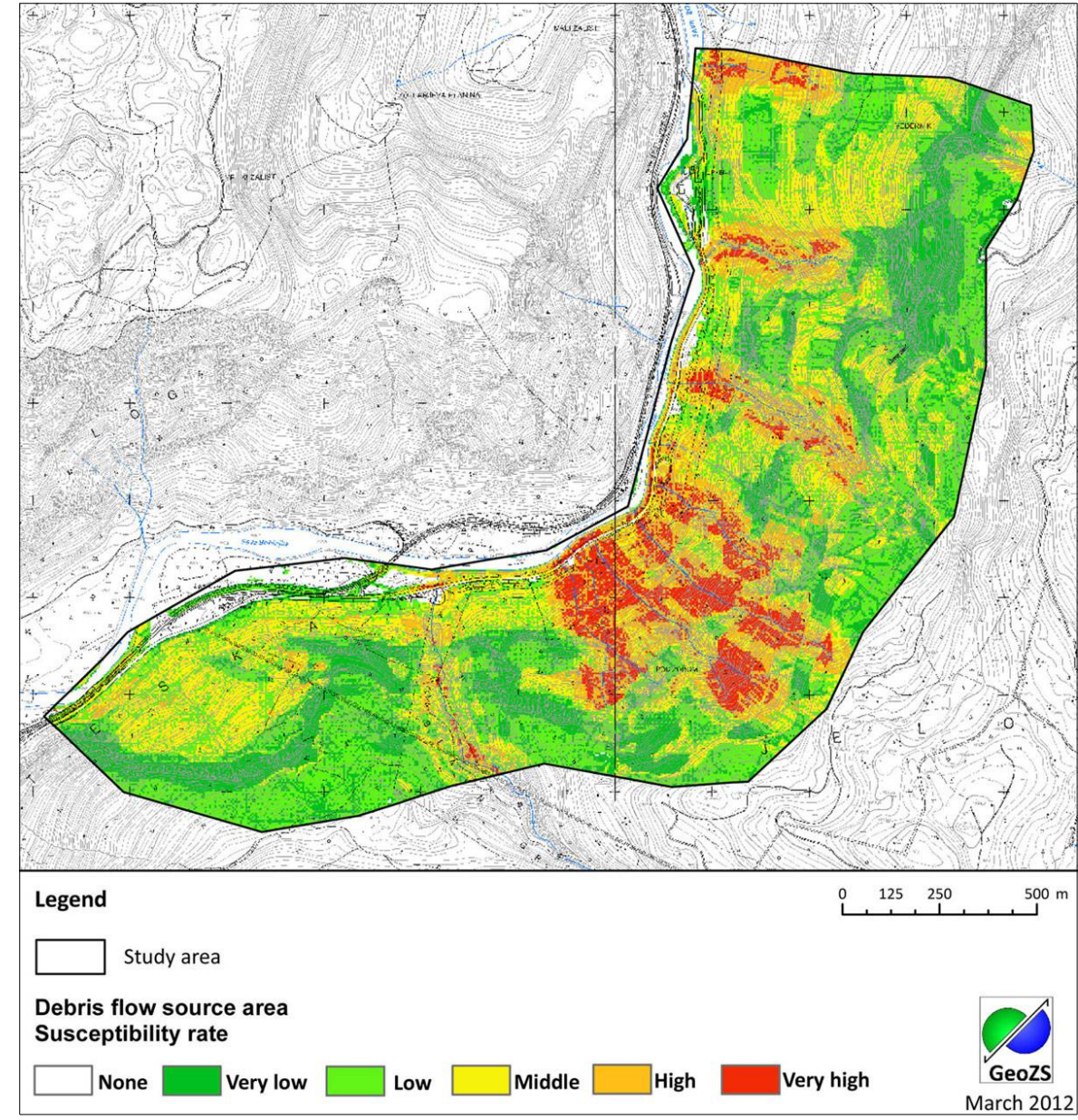

Fig. 1 - The debris-flow susceptibility map of the study area in the Sava Bohinjka River gorge Soteska.

simulation area combined with overflow probability of each related cell (this was used as Debris flow warning map - Fig. 2); and (2) a deposited area and the deposition height of each cell (not shown in the paper Scheidl 2009a, 2009b). The goal is to identify areas of debris flow deposit hazard on a debris cone. The following input data were used for the simulation: a digital elevation model (we used a DEM with a resolution of $12.5 \mathrm{~m}$ obtained from the Surveying and Mapping Authority of the Republic of Slovenia) and the following simulation parameters:

1. The number of Monte Carlo iterations (MCI number) determines the lateral overflow of the debris flow. An increase in the MCI number indicates a significant expansion of the debris flow run-out zone (Scheidl 2009a). Based on testing, we used $\mathrm{MCI}=50$.

2. The start point of the simulation of the debris flow deposit $(\mathrm{x}, \mathrm{y})$. For the start points of the simulation we used: (2a) Apex of the cone, where the debris flow deposit phase begins; the start points were obtained from the geological map created by GSS. This method was used for the calculation of the actual deposits of the debris flows, thus creating a debris flow deposit map on the debris cone; (2b) erosion-prone sites upslope where the probability of debris flow start points is very high; the starting points were obtained from the debris-flow susceptibility map (Fig. 1). This method was used for the creation of a debris-flow warning map (Fig. 2).

3. Magnitude (volume) of debris flow in $\mathrm{m}^{3}$. Torrent catchments were similar in size and relatively small. GSS estimated the magnitude according to the deposited material on the site from former debris events. Magnitude was set to $5000 \mathrm{~m}^{3}$.

4. Mobility coefficient, which was determined through testing and was set to 50 (cones closer to the valley bottom) or 100 (cones upslope). The areas of simulated deposited material were compared with actual deposited material - we selected an MC number according to greatest overlying of simulated and actual deposit.

All of the listed simulation parameters were used during the sensitivity analysis. Values of the individual simulation parame- 


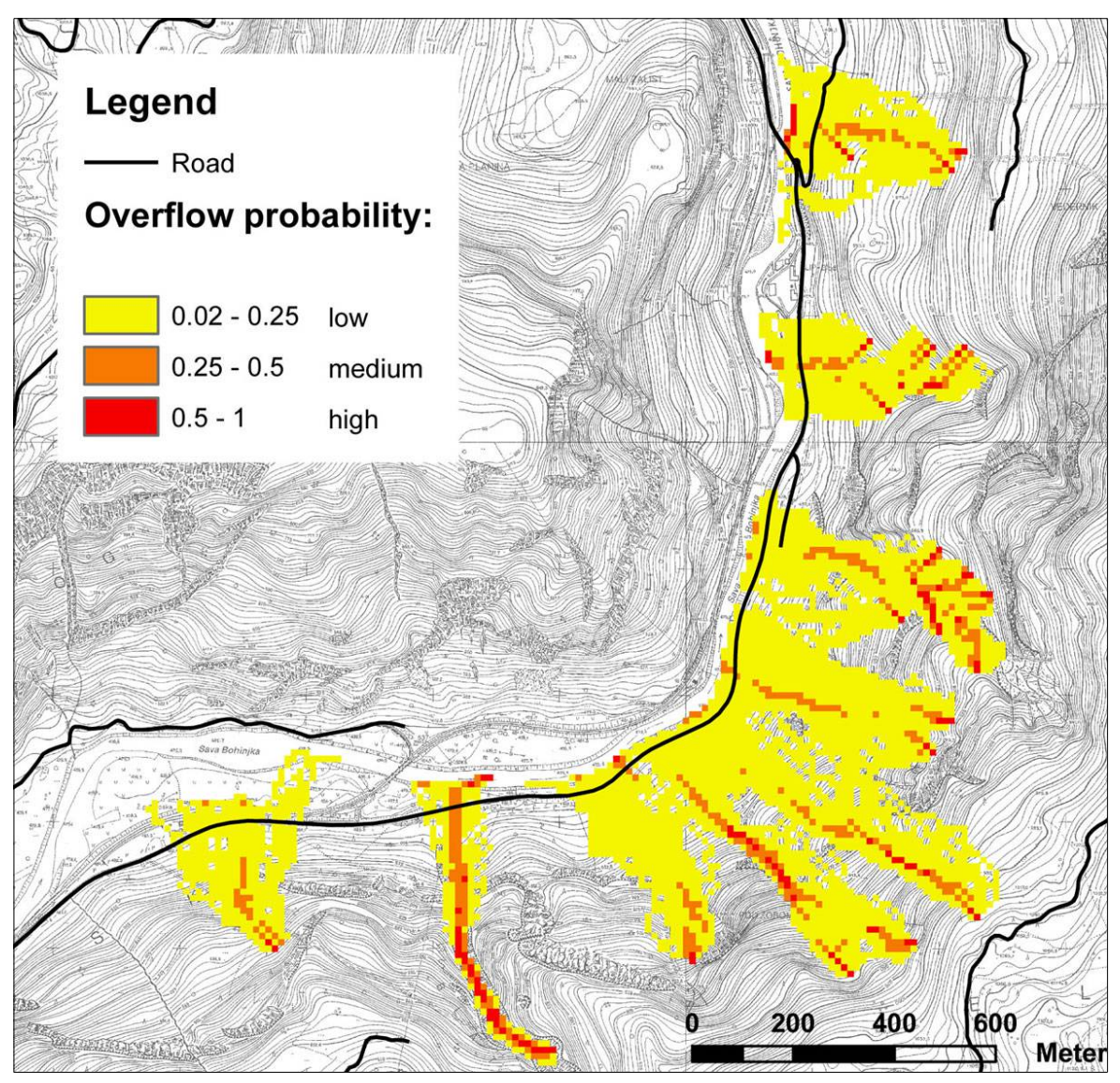

Fig. 2 - The debris-flow warning map in scale 1:15 000, prepared with the TopRunDF model. The color chart shows the debris-flow overflow probability.

ter were determined by comparison (overlying) of the area of actual deposited material (obtained from a geological map) and simulation results under various values of input parameters.

We also described the stands with the NaiS method (Frehner et al. 2005). NaiS derives its classification of forest sites in Switzerland from Ellenberg \& Klötzli (1972). The method involves describing a stand based on site and natural hazards, whereby the sites need to be divided into debris flow source or infiltration areas. NaiS determines the same target profiles for landslides, erosion, and debris flows. It distinguishes between target profiles in the debris flow source and infiltration areas, the latter defined as the area where the forest should ensure maximum water use and exert a favorable impact on soil water balance. We modified the method by selecting only three main criteria from all of the target profile criteria: site (species composition), regeneration, and vertical structure - the presence of trees in NaiS diameter classes $\left(1^{\text {st }}: 0-15 \mathrm{~cm} ; 2^{\text {nd: }}: 15-30 \mathrm{~cm}\right.$; $3^{\text {rd }}: 30-50 \mathrm{~cm} ; 4^{\text {th }}:$ over $\left.50 \mathrm{~cm}\right)$. On the basis of these criteria, we delineated the NaiS stands. Other criteria (i.e., horizontal structure, stability carriers, and conditions for re- generation (abundance of herb layer) were eliminated, since these factors did not vary significantly throughout the studied area. The decision to select only three criteria did not affect subsequent decisions on interventions. Guidelines for silvicultural measures were defined for each combination of impact area and NaiS stand, creating the following NaiS stand types:

1. well regenerated beech forest with trees in two NaiS diameter classes (10);

2. poorly regenerated beech stands with trees in two NaiS diameter classes (11);

3 . poorly regenerated beech stands with trees in only one NaiS diameter class (12);

4. shrubby European hop-hornbeam and manna ash stands (20);

5. poorly stocked European larch (Larix decidua Mill.) and Norway spruce (Picea abies Karst.) stands on exposed sites (30); 6. non-forested areas (0).

Debris flow impact areas were determined based on the warning map. We also tried to include the maximum proportion of area with a high probability of debris flows (Fig. 1). The delineation was conducted with modeling, a basic 1:5000 topographical map (TM5) on which the watersheds of individual torrents are very clearly displayed, and fieldwork observations. Within the impact areas we separately delineated the torrent channel with a buffer zone on the basis of the TM5 and the actual state; the surface areas of debris cones were obtained from the geological map made by GSS. The torrents and the fans define the area where silvicultural measures are not possible; structural measures were proposed for these areas.

\section{Results}

\section{Forest structure}

The slope angles on sample plots ranged from $15^{\circ}$ to $50^{\circ}$. The average growing stock of all sample plots was $388 \mathrm{~m}^{3} / \mathrm{ha}$ (coefficient of variation $(\mathrm{CV})=45 \%$ ). The average growing stock of the impact area was higher $\left(405 \mathrm{~m}^{3} / \mathrm{ha}\right)$ than the average for the stratum "other" (382 $\left.\mathrm{m}^{3} / \mathrm{ha}\right)$. The distribution of growing stock by $20 \mathrm{~cm}$ diameter classes was $24 \%$ in A, $53 \%$ in B, and $23 \%$ in the $\mathrm{C}$ class. The basal area was $30.9 \mathrm{~m}^{2} / \mathrm{ha}(\mathrm{CV}$ $=40 \%$ ). The upper height of the stand was 30 and $29 \mathrm{~m}$ for Norway spruce and beech, respectively. Beech was the dominant tree species in the total growing stock (64\%), followed by Norway spruce (22\%), European hop-hornbeam (4\%), European larch (3\%), and other tree species (whitebeam, Sorbus aria Cr.; silver fir; manna ash - $7 \%$ ).

The cumulative frequency of trees by $5 \mathrm{~cm}$ diameter classes indicated a negative exponential distribution (NE) and suggested correspondence with a selection forest structure (Fig. 3). However, in small diameter classes, there was a high proportion of tree species that thrive on extreme sites: European hophornbeam, whitebeam, and manna ash. These species do not typically reach large diameters and heights. Moreover, the frequency of the dominant tree species, beech and Norway spruce, was not sufficient in smaller diameter classes $(10 \leq \mathrm{DBH} \leq 25$ $\mathrm{cm})$. This indicated that the stands were rather even sized, which is a typical feature of beech stands.

The diameter distribution for the joint sample of all the plots was classified as a variable form, whereas the second closest form was a negative exponential (q-ratio $=1.38$ Fig. 3). The results were similar when curves were fitted separately for the stratum impact area $(\mathrm{q}=1.34)$. However, tree frequency on extreme sites was lower and the discrepancy of the distribution compared to the negative exponential was higher, indicating bimodality with deficits in the $3^{\text {rd }}, 4^{\text {th }}$, and $7^{\text {th }} 5 \mathrm{~cm}$ diameter classes. In the stratum "other", a negative exponential function with a small surplus of trees in diameter class 6 fitted the distribution of diameter classes best $(\mathrm{q}=$ 1.48). Divisions of the area into strata corresponded with the forest structure, as beech in the mature stage dominated the stratum impact area, while beech and European hop- 
Tab. 1 - Frequency of regeneration of dominant species in the stand by size class (N/ha).

\begin{tabular}{lccr}
\hline \multirow{2}{*}{ Species } & \multicolumn{2}{c}{ Size class } & \\
\cline { 2 - 3 } & $\begin{array}{c}\mathbf{0 . 1 m} \leq \mathbf{H} \\
<\mathbf{1 . 3 m}\end{array}$ & $\begin{array}{c}\mathbf{1 . 3 m} \leq \mathbf{H} \text { and } \\
\mathbf{D B H}<\mathbf{1 0 c m}\end{array}$ & \\
\hline Beech & 273 & 193 & 466 \\
Spruce & 489 & 129 & 618 \\
Sum & 762 & 322 & 1084 \\
\hline
\end{tabular}

hornbeam forests and hop-hornbeam and manna ash forests, characterized by smallerdiameter trees, dominated the remaining area.

Regeneration densities were relatively low compared to managed forests (Tab. 1). For beech seedlings and saplings the $\mathrm{CV}$ of the frequency was $147 \%$ and $167 \%$, respectively. The CV for Norway spruce seedlings and saplings was lower and amounted to 114 $\%$ and $95 \%$, respectively.

\section{Debris-flow modeling}

The debris flow source area map shows susceptibility to debris flows (Fig. 1). Cell size was $5 \times 5 \mathrm{~m}$. Coordinates from areas with very high susceptibility rate (areas where the probability of debris flows exceeds 57 $\%)$ were used as a starting points of debris flow in the TopRunDF model, thus creating the warning map.

The next result of the modeling was the debris flow warning map (Fig. 2), which is the first step in the protection process. The result is an inundated simulation area combined with the overflow possibility of each related cell. The map shows the maximum potential debris flow reach and is suitable to be used as a warning map.

\section{NaiS stands and measures}

The delineated debris flow impact area was 42 ha or $20 \%$ of the total area (207 ha). Torrent channel and debris cones on which silvicultural management was not possible accounted for 16 ha or $40 \%$ of the total impact area. On the remaining $60 \%$ (26 ha) of the impact area silvicultural measures were necessary. Proportions of NaiS stands in the impact area (Fig. 2 and Fig. 4) and necessity of measures are as follows (Fig. 5):

- 10: $1.2 \%$ (0.3 ha) - low necessity of measures (in the next 30-50 years);

- 11: $60.3 \%$ (15.6 ha) - medium necessity of measures (in the next 10-30 years);

- $12: 3.1 \%$ ( $0.8 \mathrm{ha})$ - high necessity of measures (in the next $0-10$ years);

- 20: $35.4 \%$ (8.8 ha) - low necessity of measures (in the next $30-50$ years).

To create a silvicultural plan, we need spatially explicit data on forest stands with emphasis on debris flow protective functions (NaiS - Fig. 4) and elements of natural hazard. Forest protective functions and optimal

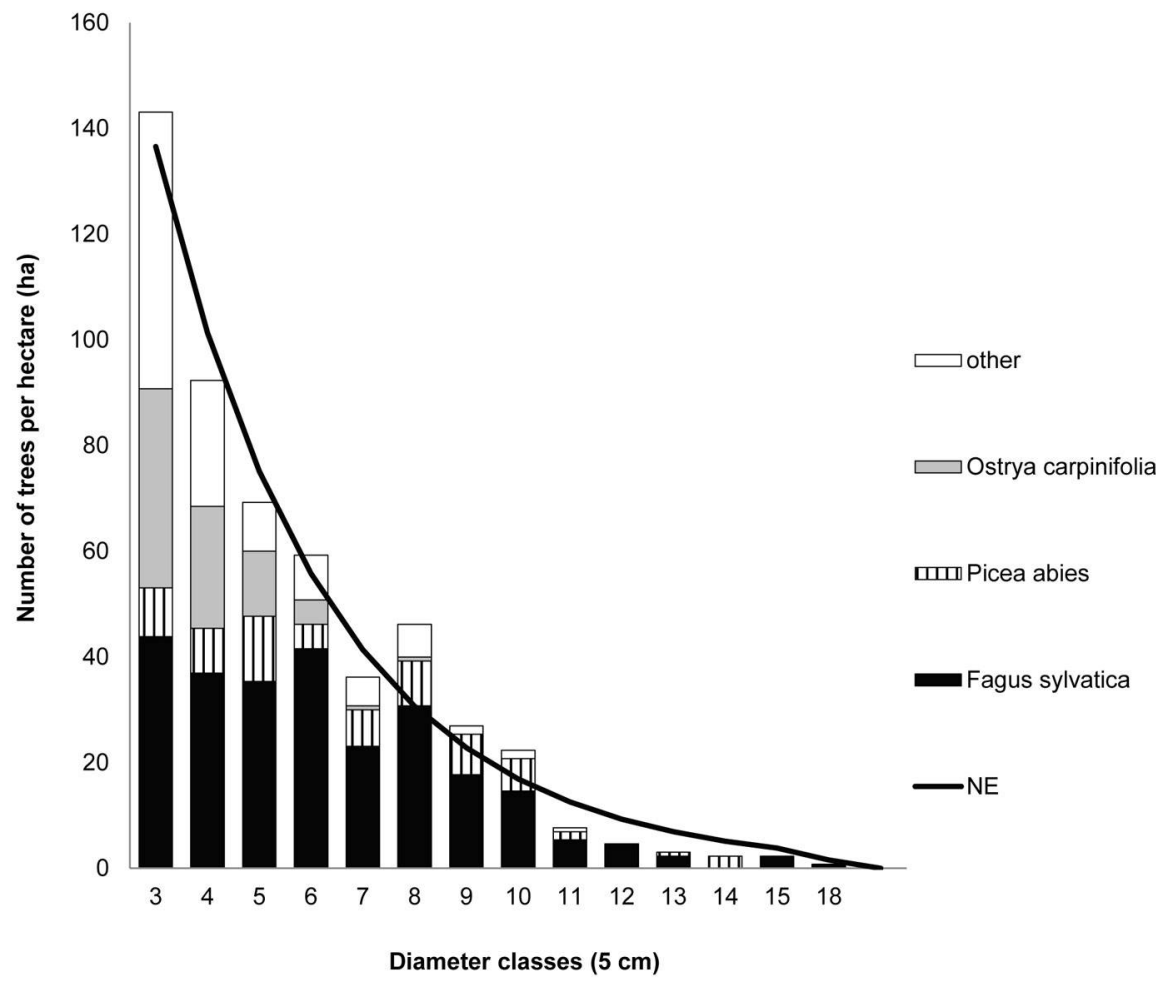

Fig. 3 - Frequency distribution of tree species by diameter class and adjusted curve (NE).

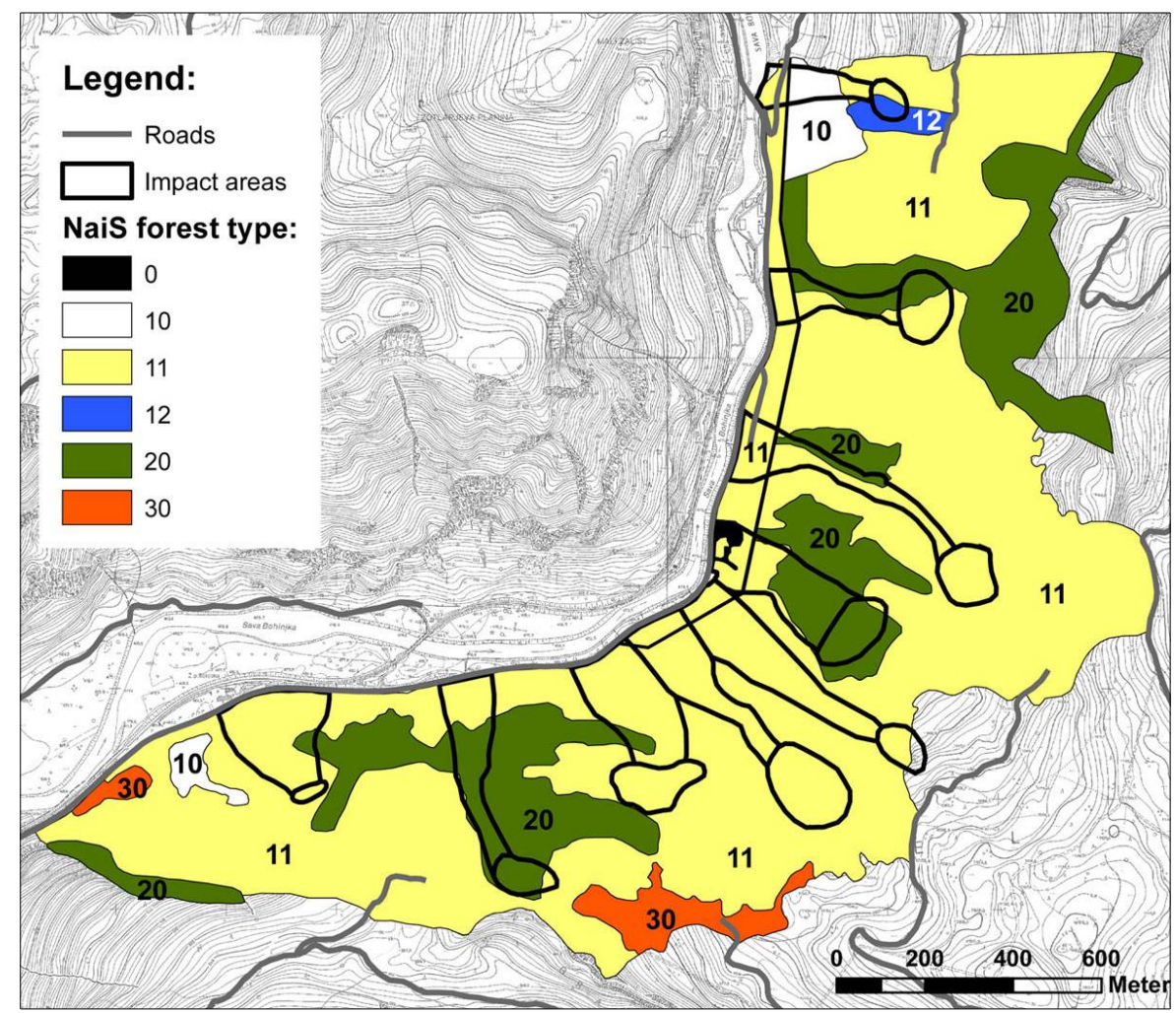

Fig. 4 - Stands delineated with the NaiS methodology (Frehner et al. 2005). Numbers denote NaiS stands. Black lines show debris flow impact areas, divided to source and infiltration areas. The grey line is a state road. The legend for NaiS stands is described in the methods. Scale: $1: 15000$. 


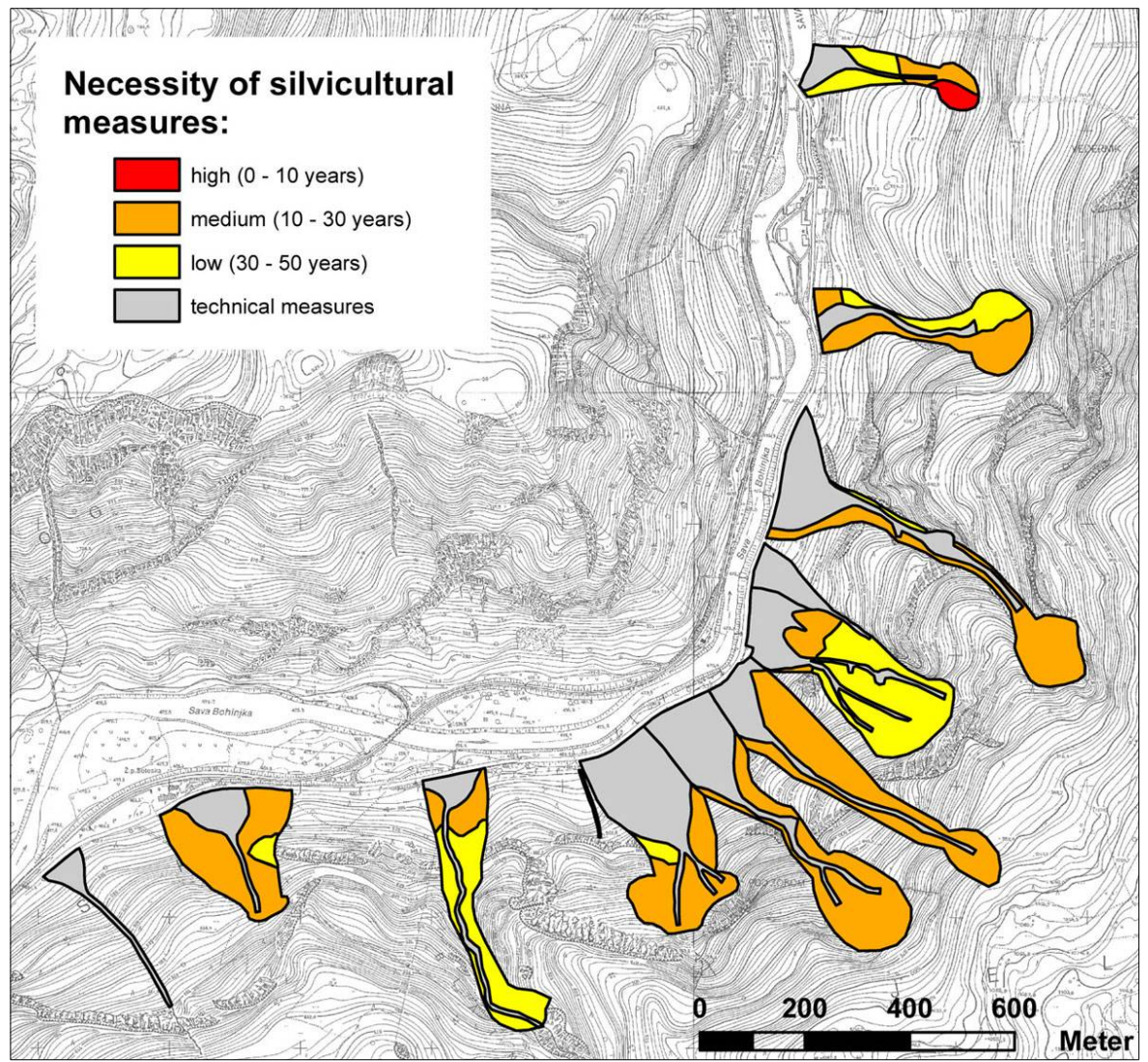

Fig. 5 - Necessity of silvicultural measures in impact areas according to NaiS stands. In the impact areas, we estimate that the necessity of measures is high in NaiS stands 12 , medium in NaiS stands 11 and 20, and low in NaiS stand 10.

stand structures depend on stand location in the broader debris flow impact area. We divided the stands to source area and infiltration area stands. Combined with forest type (NaiS stands), this served as the basis for the proposed silvicultural measures. With aging

stands and decreasing mechanical stability, management in the impact areas seems crucial for sustaining protection effects. For each type of forest $(10,11,12,20$ - see above) a detailed silvicultural plan was defined. An example of planned silvicultural

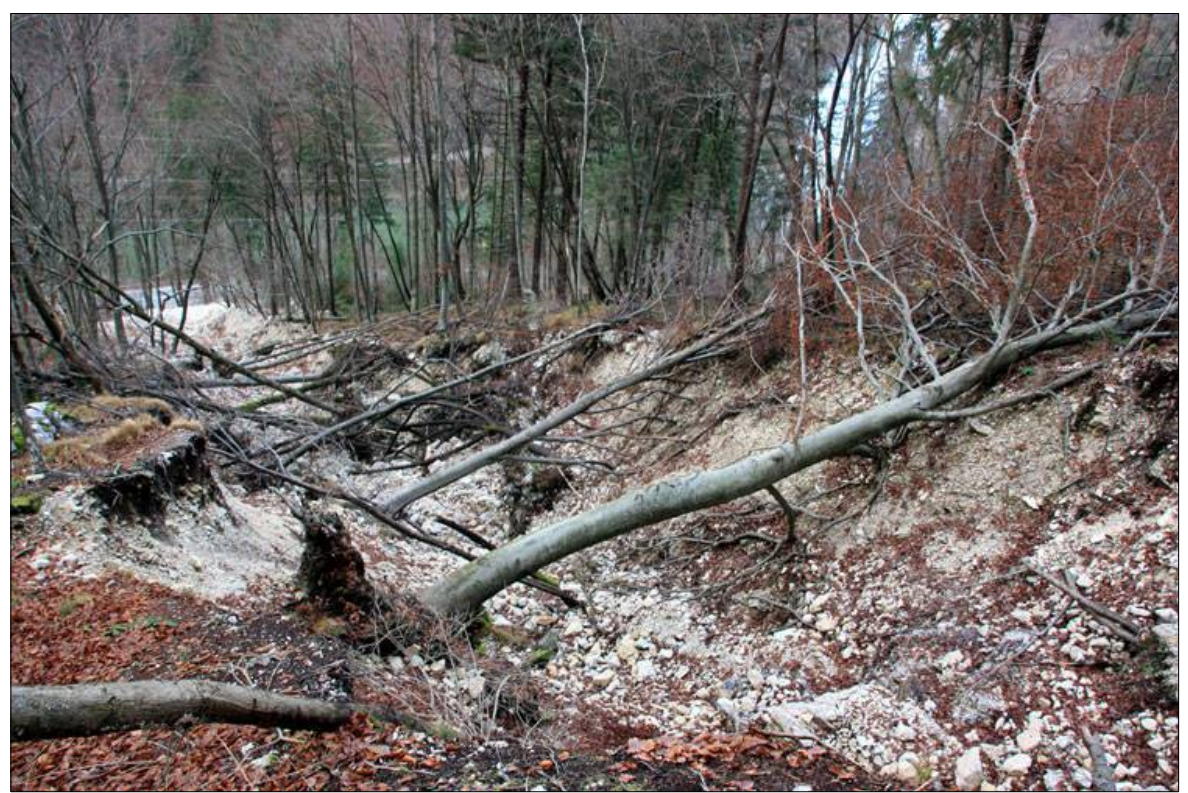

Fig. 6 - A typical torrential channel with dead trees. measures in a poorly regenerated beech stand with trees in just one NaiS diameter class (12) may look like this:

- In the debris flow source area: Preservation of woody vegetation. If the slope is not too steep, spatially explicit regeneration patches ( 0.06 ha in size) are formed; on regenerated areas the gaps should not exceed 0.12 ha. Oversized gaps on steep slopes encourage the development of grass, thus hindering regeneration development. Due to shallow soil and steep slopes, maintaining smaller-dimension trees is preferable. The density of trees with $\mathrm{DBH} \leq 30$ $\mathrm{cm}$ should be high, as a dense, interconnected root system keeps the soil together, reducing the possibility of landslides or erosion scars that can trigger debris flow. Coppicing is preferred. Large-dimension trees $(\mathrm{DBH} \geq 40 \mathrm{~cm})$ should be removed. Hop hornbeam and manna ash should be favored if present.

- In the infiltration area: Promotion of perpetual regeneration with small gaps. Regeneration is favored on areas of at least $200-500 \mathrm{~m}^{2} \mathrm{ha}^{-1}$ or on at least $3 \%$ of the area. When regeneration reaches DBH 5$10 \mathrm{~cm}$, the remaining upper story trees are removed. Smaller-diameter trees $(\mathrm{DBH} \leq$ $40 \mathrm{~cm}$ ) should dominate the stand structure. In order to achieve a small-scale, uneven-aged and uneven-sized structure (trees in at least 2 NaiS diameter classes), spatially explicit regeneration patches should be created.

\section{Discussion}

\section{Forest structure}

Single-tree selection maintains a suitable structure for protection forests, since smallscale, uneven-structured stands provide continuous protection (Ott et al. 1997, O'Hara 2006). A small-scale, uneven aged structure is also suitable for mimicking natural disturbances, as Alpine beech forests are characterized by frequent small-scale and intermediate-severity disturbances (Leibundgut 1982, Splechtna et al. 2005). If protection forests are managed, several balanced states can be achieved (Schütz 2001a). In the study area, the target profile of the selection forest should be adjusted to a forest protection function and debris-flow protection in particular. Target stands should constitute smaller-diameter trees (e.g., target $\mathrm{DBH} \leq 40$ $\mathrm{cm}$ ), lower growing stock, higher frequency of trees in lower diameter classes, and denser regeneration (higher $q$ values of the negative exponential curve). The high proportion of beech and the specifics of skidding render it difficult to achieve a single-tree selection structure on the study area; group selection is more feasible. However, there is a significant discrepancy between the present stand condition and a balanced selection model of 
the target profile. The interval of balanced growing stock for a mixed selection forest can be developed from the upper height of the stand multiplied by a factor of 10 or 11 (Diaci \& Firm 2011). Considering the characteristics of beech growth in protection forests, the balanced growing stock is lower than that in mixed forests (Schütz 2001b), we used a factor of 9 or 10 , which was also driven by our desire to achieve a forest structure adjusted to protective functions. In our example an upper height of $30 \mathrm{~m}$ produces an interval estimate for balanced growing stock of 270-300 $\mathrm{m}^{3} \mathrm{ha}^{-1}$. The actual growing stock was, therefore, about $100 \mathrm{~m}^{3} \mathrm{ha}^{-1}$ too high. Schütz (2001a) proposes an even lower growing stock $\left(250 \mathrm{~m}^{3} \mathrm{ha}^{-1}\right)$ for more productive Langula-type beech selection forests Given his assumptions, the basal area of the study area was about $10 \mathrm{~m}^{2} \mathrm{ha}^{-1}$ too high The same author reported the following dis tribution of growing stock by diameter class for a beech forest on southern expositions in the Swiss Jura (20-30 cm: $15 \% ; 35-50 \mathrm{~cm}$ : $34 \%$; over $55 \mathrm{~cm}$ : $51 \%$ ). Since European hop-hornbeam and other non-successional tree species accounted for a large proportion of growing stock in lower diameter classes in this study, the growing stock of this diameter class was suitable. The growing stock of the medium-diameter class was slightly too high The upper diameter class accounted for a minor proportion of the total growing stock, which was appropriate since these are protection forests on steep slopes and shallow soil, where large-diameter trees have proven to be unstable.

In general, there was little regeneration in Soteska. Duc (1991) reported that in a selection forest (orig. Planterwald) the minimum required frequency of 50-130 cm height trees was between 310 and 830 ha $^{-1}$; Schütz (2001a) proposed $90-740 \mathrm{ha}^{-1}$ as the minimum. In the study area, we found 237 beech individuals and 489 spruce individuals, a total of 762 stems ha ${ }^{-1}$ in the seedling class. The proposed minimum frequency of regeneration was not entirely comparable to this study, as we inventoried regeneration from $10 \mathrm{~cm}$, knowing that the mortality of lower regeneration is higher. That considered, we deem the frequency of regeneration to be at the lower end of the minimum range for a selection forest. In the $0-8 \mathrm{~cm}$ diameter class, Schütz (2001a) proposed a minimum of 2101460 individuals, while Duc (1991) proposed 257-1933 individuals in the 0.1-7.4 cm class. In the sapling class $(130 \mathrm{~cm}$ height to DBH $\leq 10 \mathrm{~cm}$ ) we counted 193 beech individuals and 129 spruce individuals, a total of 322 stems $\mathrm{ha}^{-1}$. Trees in this class were very sparse in Soteska, which is also evident from Fig. 3 that shows only about $55 \mathrm{ha}^{-1}$ beech and spruce individuals in diameter class 3 . Regeneration was present mostly in gaps, but we nevertheless recorded frequent small- scale regeneration-free gaps. Beech regenerated poorly on very rocky terrain, where spruce regenerated well. Where there is sufficient light, light demanding tree species (European hop-hornbeam, manna ash) dominate extreme terrain.

\section{Debris-flow modeling}

The sensitivity analysis of the TopRunDF simulation model showed that the mobility coefficient (MC) is the most significant factor for debris flow modeling. Specific relief (steep slope on debris flow run-out zones) sets Soteska clearly apart from the circumstances in which the empirical equation for the MC calculation was made. It turned out that at steeper torrent slopes, MC values change very little, indicating poor sensitivity of the empirical equation to higher slope angle values. This indicates that the empirical equation was developed in conditions with significantly shallower slopes, hence the distorted results for steeper slopes and more realistic results for shallower slopes. Overflow at higher mobility coefficients produced better and more likely results. For our study area it would be necessary to develop a different empirical equation based on past events (debris flows), or to modify the existing equation to adjust for torrents with steeper slopes. The problem with empirical models such as the TopRun DF model is that they are constrained by the conditions in which they were developed. In testing the impact of the number of Monte Carlo iterations, we found that the best results are produced when the value is 50 . This was also established by Scheidl \& Rickenmann (2009). Although modeling is typically the principal method for the creation of a hazard map, it is also appropriate for the creation of a warning map. The model has the following advantages: ease of use, speed of calculation (most simulations take only a few seconds), and rapid, simple, and undemanding acquisition of input data (parameters) for modeling. But it also has downsides: (i) Empiricism of the model. The model has its limitations, as it is based on the specific conditions in which it was created. The mobility coefficient turned out to be the biggest limitation. (ii) The necessary number of simulations to acquire probable results: probable results are achieved through a high number of simulations with a variety of parameter values.

According to the rules for the classification of areas into risk classes (Official Gazette 2007), a warning map must include the boundary line of the potential reach of the event but not the probability of the event occurring. In our proposal for the creation of a warning map, we used modeling to show the maximum scale of potential debris flow events as well as the probability of occurrence (Fig. 2), which is a step forward from an ordinary warning map. Detailed mathe- matical modeling could also be used to create a hazard map, but TopRunDF does not handle this feature. This is because the rules determine guidelines for the classification of hazard classes, where debris-flow velocity is a criterion along with the debris-flow depth, but the model used in this study does not produce speed data. To determine accurate parameters of debris overflow it is necessary to use more complex mathematical models in which simulations are based on hydraulic equations (dynamic and continuity equation) and the debris-flow rheology must be taken into account (e.g., FLO-2D - O'Brien 2006). In this study we used a $12.5 \mathrm{~m}$ resolution DEM for modeling; in the future we should, as a matter of necessity, include LiDAR images, which are very precise and have been widely used elsewhere (Lopez Saez et al. 2011).

\section{NaiS stands and measures}

For practical and economic reasons, we would probably delineate a protection forest in a larger area; for example, a $50 \mathrm{~m}$ wide buffer zone surrounding impact areas could be added. For preventive (protective) reasons alone, management would be rational on the entire surface of the protective forests. It is particularly important to carry out measures on debris flow source areas. The impact of forests in transition and run-out phases is smaller though not negligible. Mature trees dominate torrent areas and debris fans; regeneration is absent and cannot be reestablished in the short term due to deposited material from former debris flow events. Rocky material causes the die-back of trees on these areas therefore limiting the efficiency of debris flow forest mitigation. On the other hand, some authors found that forests have a significant impact on shallow debris flows. By limiting flow volume forests act as an impediment that shortens the run-out zone. On steep slopes forests can even stop it (Guthrie et al. 2010).

Several hydrotechnical measures are possible in areas of torrents and deposited material, their main function being to protect the infrastructure (road) below. In torrent-to-fan transitions, flexible net barriers whose function is to retain smaller debris flows and coarse material should be erected. On torrents where depth and lateral erosion is pronounced (Fig. 4), the torrent's beds should be checked with ground sills and a series of check dams should prevent incision of torrent channels and collapse of their banks. On torrents that pose a direct risk to infrastructure, deflection dams should be constructed to redirect torrent flow and debris material to lower-risk areas. In torrent channels (Fig. 6) that contain a large number of dead trees due to lateral erosion (Mazzorana et al. 2009), trees must be removed or cut to shorter pieces (1-2 m). 
In the remaining protection forests outside the debris flow impact areas, it is recommended to remove dead trees from torrent channels, establish a small-scale uneven aged structure, and create spatially-explicit regeneration patches (small-scale regeneration patches of $200-500 \mathrm{~m}^{2}$ ). The portion of conifers should be preserved, in particular fir and larch; spruce is less suitable. Root tensile and root cohesion tests in Italian Alps show that beech roots are significantly more resistant and offer greater reinforcement of soil than spruce roots (Bischetti et al. 2005 2009, Vergani et al. 2012). In addition, spruce is less suitable for these sites as compared to beech, due to its susceptibility to bark beetles, (three times) lower mechanical resistance to rockfall and weak compartmentalization of trunks after damage (Stokes et al. 2005).

Annual field surveys are required to monitor the state of the forest stands since factors considering protection forest are the most important criterion among other functions (Santopuoli et al. 2012).

\section{Conclusions}

Lower timber value makes beech forests and protection forests less interesting for management, particularly on steep slopes. Asymmetrical crowns and the large dimensions of trees make management more demanding and dangerous. Numerous protection forests in the Alps have therefore been left unmanaged in recent decades; this is even more true for forests on massifs in southeastern Europe (Dinaric Alps, Carpathian Mountains). Protection forests undoubtedly need active management to sustain their protection role. To objectively delineate protection forests it is essential to define impact areas of all present natural hazards. This study uses modeling as an objective method for delineating protection forest with a debris flow hazard. Characteristics of a given forest in impact areas must be compared to characteristics defined in target profiles for specific site and natural hazard. Discrepancy between them leads us to create a detailed spatially explicit silvicultural plan which tends to maximize the protection function of the given stands. In protection forests, a selection structure is ideal since it mimics natural disturbances and ensures continuous protection. However, this approach renders it difficult to be applied because of a high proportion of beech and difficult skidding conditions that make logging activities economically less attractive. A more suitable approach would be a small scale group selection. Within forests in the debris flow source area, silvicultural measures tend to ensure maximal water use, preserve smalldiameter and high density woody vegetation (which reinforce soils) and avoid large gap openings to prevent development of grasses and reducing possibility of landslides and erosion scars that can trigger debris flow. In the infiltration area, the goals of silvicultural measures are similar. Perpetual regeneration is favored across the whole area or distributed evenly in small gaps, thereby resulting in uneven-aged and uneven-sized structure. Smaller diameter trees $(\leq 40 \mathrm{~cm})$ are preferred, since larger trees have proven to be unstable on steep slopes. On torrents and areas where rocky debris prevails, mature trees are damaged and regeneration is absent. Forests on these areas do not play such a crucial role in mitigating debris flow overflow, therefore hydrotechnical measures (deflection dams, flexible net barriers, ground sills, check dams, etc.) are needed.

In the future it is necessary to adopt regulations on debris flows, or amend the existing legislation. Geology and forestry professionals and hydraulic engineers need to become involved in creating a legal basis for the comprehensive treatment of risks to infrastructure by natural hazards and the assessment of the impact of forests: geologists with geological, avalanche, and debris flow susceptibility maps, etc.; hydraulic experts with their know-how of hydraulics (rheology) and hydrology; and forestry experts with silvicultural practices (long-term spatial and temporal dynamics) and the management of protection forests (evaluation of protective functions, adjusted inventories of protection forests). Researchers should be brought together in a European network to facilitate the improvement of knowledge on beech protection forests.

\section{Acknowledgments}

We would like to thank the Bled Regional Unit of the Slovenia Forestry Service for all the data provided. This research was funded by the applied project: "Protection forests: developmental dynamics, risk assessment, combining and improving silviculture and exploitation technologies" (L4 - 2244) and the Pahernik foundation.

\section{References}

ARSO (2006). Podnebne razmere v Sloveniji (obdobje 1971-2000) [Climatic conditions in Slovenia (1971-2000)]. Agencija Republike Slovenije za okolje, Ljubljana, Slovenia. [in Slovenian] [online] URL: http://www.arso.gov.si/vreme/pod nebje/podnebne_razmere_Slo71_00.pdf

Bavec M, Budkovič T, and Komac M. (2005). Geohazard - geološko pogojena nevarnost zaradi procesov pobočnega premikanja. Primer občine Bovec [Geohazard - geology of the slope movement process. Example from the municipality of Bovec]. Geologija 48/2: 303-310. [in Slovenian] Berger F, Rey F (2004). Mountain protection forests against natural hazards and risks: new French developments by integrating forests in risk zoning. Natural Hazards 33: 395-404. - doi: 10.1023/B:NHAZ.0000048468.67886.e5
Bischetti GB, Chiaradia EA, Simonato T, Speziali B, Vitali B, Vullo P, Zocco A (2005). Root strength and root area ratio of forest species in Lombardy (Northern Italy). Plant and soil 278: 11-22. - doi: 10.1007/s11104-005-0605-4 Bischetti GB, Chiaradia EA, Epis T, Morlotti E (2009). Root cohesion of forest species in the Italian Alps. Plant Soil 324: 71-89. - doi: 10.1007/s11104-009-9941-0

Brang P, Schönenberger W, Frehner M, Schwitter R, Thormann JJ, Wasser B (2006). Management of protection forests in the European Alps: an overview. Forest Snow and Landscape Research 80: 23-24.

Cetina M, Rajar R, Hojnik T, Zakrajšek M, Krzyk M, Mikoš M (2006). Case study: numerical simulations of debris flow below Stože, Slovenia. Journal of Hydraulic Engineering 132 (2): 121130. - doi: 10.1061/(ASCE)0733-9429(2006)13 2:2(121)

Diaci J, Firm D (2011). Long-term dynamics of a mixed conifer stand in Slovenia managed with a farmer selection system. Forest Ecology and Management 262: 931-939. - doi: 10.1016/j.for eco.2011.05.024

Dorren LKA, Berger F (2006). Panarchy and sustainable risk prevention by managing protection forests in mountain areas. In: "RISK 21 - Coping with risks due to Natural Hazards in $21^{\text {st }}$ century" (Amman WJ, Dannenmann S, Vulliet L ed). Monte Verita, Ascona, Switzerland, pp. 203214.

Duc VP (1991). Untersuchungen zur dynamik des nachwuchses im plenterwald [Studies of the offspring dynamics in selection forests]. Schweizerische Zeitschrift für Forstwesen 142: 299-319. [in German]

Ellenberg H, Klötzli F (1972). Waldgesellschaften und Waldstandorte der Schweiz [Forest communities and forest sites in Switzerland]. Mitteilungen der schweizerische Anstalt für das forstliche Versuchswesen, vol. 48, pp. 930. [in German] Ellenberg H (1996). Vegetation Mitteleuropas mit den Alpen. Ökologischer, Dynamischer und Historischer Sicht [Vegetation ecology of central Europe] $\left(5^{\text {th }}\right.$ edn). Eugen Ulmer Verlag, Stuttgart, Germany, pp. 1095. [in German]

FMP (2003). Forestry Management Plan for FMU Jelovica 2002-2011. Slovenia Forestry Service, Forestry unit, Bled, Slovenia.

Forest Europe (2010). Expert Level Meeting Geneva. Geneva, Switzerland. [online] URL: http://www.foresteurope.org/eng/Commitments/ Documents/Meetings_2010/FOREST+EUROPE +Expert+Level+Meeting+Geneva.9UFRrUYo. ips

Frehner M, Wasser B, Schwitter R (2005). Nachhaltigkeit und Erfolgskontrolle im schutzwald [Sustainability and control method in protection forests]. Wegleitung für Pflegemassnahmen in Wäldern mit Schutzfunktion, Vollzug Umwelt. Bundesamt für Umwelt, Wald und Landschaft, Bern, Switzerland, pp. 564.

Frei C (1995). An Alpine precipitation climatology based on high-resolution rain-gauge observations. MAP Newsletter 3: 46-47. 
Giamboni M, Wehrli A (2008). Improving the management of protection forests in Switzerland - The project SilvaProtect - CH. In: Proceedings of the " $11^{\text {th }}$ Interpraevent Congress" (Mikoš M, Huebl J, Koboltschnig G eds). Dornbirn (Vorarlberg, Austria), 26-30 May 2008, vol. 2, pp. 469480.

Guthrie RH, Hockin A, Colquhoun L, Nagy T, Evans SG, Ayles C (2010). An examination of controls on debris flow mobility: Evidence from coastal British Colombia. Geomorphology 114: 601-613. - doi: 10.1016/j.geomorph.2009.09.021 Janowiak MK, Nagel LM, Webster CR (2008). Spatial scale and stand structure in northern hardwood forests: implications for quantifying diameter distributions. Forest Science 54: 497506. [online] URL: http://www.ingentaconnect. com/content/saf/fs/2008/00000054/00000005/art 00004

Kajfež-Bogataj L (1996). Nalivi v Sloveniji [Storms in Slovenia]. Sodobno kmetijstvo 29: 422-424. [in Slovenian]

Komac M (2005). Verjetnostni model napovedi nevarnih območij glede na premike pobočnih mas - primer občine Bovec [Probabilistic model of slope mass movement susceptibility - a case study of Bovec municipality, Slovenia]. Geologija 48/2: 311-340. [in Slovenian]

Korpel S (1995). Die Urwälder der Westkarpaten [Virgin forests of west Carpathian region]. Gustav Fischer Verlag, Stuttgart, Jena, New York, pp. 310. [in German]

Leibundgut H (1982). Europäische Urwälder der Bergstufe [European mountain virgin forests]. Haupt P, Berlin, pp. 308. [in German]

Lopez Saez J, Corona C, Stoffel M, Gotteland A, Berger F, Liébault F (2011). Debris-flow activity in abandoned channels of the Manival torrent reconstructed with LiDAR and tree-ring data. $\mathrm{Na}$ tural Hazards and Earth System Sciences 11: 1247-1257. - doi: 10.5194/nhess-11-1247-2011

Marinček L, Carni A (2002). Komentar k vegetacijski karti gozdnih združb Slovenije v merilu 1:400.000 [Comment on vegetation map of forest associations of Slovenia in 1:400.000 scale]. Založba ZRC, Biološki inštitut Jovana Hadžija ZRC SAZU, Ljubljana, Slovenia, pp. 60. [in Slovenian]

Mayer H, Ott E (1991). Gebirgswaldbau, Schutzwaldpflege. Ein waldbaulicher Beitrag zur Landschaftsökologie und zum Umweltschutz [Mountain forests, protection forests tending. A silvicultural contribution to landscape ecology and nature conservation]. Gustav Fischer Verlag, Stuttgart, New York, pp. 435. [in German]

Mazzorana B, Zischg A, Largiader A, Hübl J (2009). Hazard index maps for woody material recruitment and transport in alpine catchments. Natural Hazards and Earth System Sciences 9: 197-209. - doi: 10.5194/nhess-9-197-2009

Meyer P, Tabaku V, von Lüpke B (2003). Structural characteristics of Albanian beech (Fagus sylvatica L.) virgin forests - Deductions for semi-natural forestry. Forstwiss Centralblatt 122 : 47-58. - doi: 10.1046/j.1439-0337.2003.02041.x
Mikoš M, Cetina M, Brilly M (2004). Hydrologic conditions responsible for triggering the Stože landslide, Slovenia. Engineering Geology 73 (3/4): 193-213. - doi: 10.1016/j.enggeo.2004.01. 011

Mikoš M, Fazarinc R, Majes B, Rajar R, Zagar D, Krzyk M, Hojnik T, Cetina M (2006). Numerical simulation of debris flows triggered from the Strug rock fall source area, W Slovenia. Natural Hazards and Earth System Sciences 6: 261-279. - doi: 10.5194/nhess-6-261-2006

Mizunaga H, Nagaike T, Yoshida T, Valkonen S (2010). Feasibility of silviculture for complex stand structures: designing stand structures for sustainability and multiple objectives. Journal of Forest Research 15: 1-2. - doi: 10.1007/s10310009-0177-x

Motta R, Haudemand JC (2000). Protective forests and silvicultural stability. An example of planning in the Aosta valley. Mountain Research and Development 20: 74-81. - doi: 10.1659/02 76-4741(2000)020[0180:PFASS $] 2.0 . C O ; 2$

Official Gazette (1993). Act on forests. Official Gazette RS, No. 30/93, Republic of Slovenia. [in Slovenian]

Official Gazette (2007). Rules on methodology to define flood risk areas and erosion areas connected to floods and classification of plots into risk classes. Official Gazette RS, No. 60/07, Republic of Slovenia. [in Slovenian]

Ott E, Frehner M, Frey HU, Lüscher P (1997). Gebirgsnadelwälder: praxisorientierter Leitfaden für eine standortgerechte Waldbehandlung [Mountain coniferous forests: a practical guide for site-specific forest treatment]. Verlag Paul Haupt, Bern, Stuttgart, Wien, pp. 287. [in German]

Otto HJ (1994). Waldökologie [Forest ecology]. Eugen Ulmer Verlag, Stuttgart, pp. 391. [in German]

O'Brien JS (2006). FLO-2D: user's manual (v. 2006.01). FLO-2D Software, Inc., Nutrioso, AZ, USA. [online] URL: http://www.flo-2d.com/

O'Hara KL (2006). Multiaged forest stands for protection forests: concepts and applications. Forest, Snow and Landscape Research 80: 45-55 [online] URL: http://www.wsl.ch/dienstleistungen/publikationen/pdf/7498.pdf

Picket STA, White PS (1985). The ecology of natural disturbance and patch dynamics. Academic Press, New York, USA, pp. 472.

Santopuoli G, Requardt A, Marchetti M (2012). Application of indicators network analysis to support local forest management plan development: a case study in Molise, Italy. iForest 5: 3137. - doi: 10.3832/ifor0603-009

Scheidl C, Rickenmann D (2009). Empirical prediction of debris-flow mobility and deposition on fans. Earth Surface Processes and Landforms 35: 157-171.

Scheidl C (2009a). Prediction of debris-flow mobility and deposition on torrential fans. PhD thesis, University of Natural resources and Applied Life Sciences, Vienna, Austria, pp. 198.

Scheidl C (2009b). English manual for using
TopRunDF (v. 1.0). Web site, pp. 9. [online] URL: http://www.debris-flow.at/index.php/en/ download-en/category/6-toprundf-doc

Schima J, Singer F (2008). Waldentwicklungsplan - Richtlinie über Inhalt und Ausgestaltung-Fassung 2006 [Forest development plan - Directive on the content and design - Version 2006]. BMLFUW Lebensministerium, pp. 92. [in German]

Schütz JP (1996). Bedeutung und Möglichkeiten der biologischen Rationalisierung im Forstbetrieb [Importance and possibilities for biological rationalization of forest utilization]. Schweizerische Zeitschrift für Forstwesen 147: 315-349. [in German]

Schütz JP (2001a). Der Plenterwald und weitere Formen strukturierter und gemischter Wälder [The selection forest and other forms of structured and mixed forests]. Parey, Berlin, pp. 240. [in German]

Schütz JP (2001b). Opportunities and strategies of transforming regular forests to Irregular. Forest Ecology and Management 151: 87-94. - doi: 10.1016/S0378-1127(00)00699-X

Seidl R, Rammer W, Lexer MJ (2011). Adaptation options to reduce climate change vulnerability of sustainable forest management in the Austrian Alps. Canadian Journal of Forest Research 41: 694-706. - doi: 10.1139/x10-235

Sodnik J, Mikoš M (2006). Ocena magnitud drobirskih tokov v izbranih hudourniških območjih v Sloveniji [Estimation of magnitudes of debris flows in selected torrential watersheds in Slovenia]. Acta geographica Slovenica 46/1: 93-123. [in Slovenian]

Splechtna BE, Gratzer G, Black BA (2005). Disturbance history of a European old-growth mixed-species forest - A spatial dendro-ecological analysis. Journal of Vegetation Science 16: 511522. - doi: 10.1111/j.1654-1103.2005.tb02391.x Stokes A, Salin F, Kokutse AD, Berthier S, Jeannin H, Mochan S, Dorren L, Kokutse N, Abd Ghani M, Fourcaud T (2005). Mechanical resistance of different tree species to Rockfall in the French Alps. Plant and Soil 278: 107-117. - doi: 10.1007/s11104-005-3899-3

Vergani C, Chiaradia EA, Bischetti GB (2012). Variability in the tensile resistance of roots in Alpine forest tree species. Ecological Engineering 46: 43-56. - doi: 10.1016/j.ecoleng.2012. 04.036

Wieczorek GF, Glade T (2005). Climatic factors influencing occurrence of debris flows. In: "Debris-flow Hazards and Related Phenomena" (Jakob M, Hungr O ed). Springer, Berlin, Germany, pp. 325-362.

Ziegner KDI (2002). Einzugsgebiete in Alpinen Regionen Neue Planungsinstrumente für das Naturraum Management (EGAR) [Catchment areas in the Alpine regions. New planning tools for the management of natural areas (EGAR)]. Amt der Tiroler Landesregierung, Innsbruck, Austria, pp. 29. [in German] 